\title{
The Effectiveness of Semi-Natural Rearing of Coho Salmon (Oncorhynchus kisutch) at the Nitinat River Hatchery, British Columbia
}

\author{
Robert Brouwer ${ }^{1}$, Amanda Ross ${ }^{1}$, Ian Trepanier ${ }^{1}$ and Ronald W. Tanasichuk ${ }^{2, *}$ \\ ${ }^{I}$ Fisheries and Oceans Canada, Nitinat River Hatchery, P.O. Box 369, Port Alberni, BC, V9Y 7M8, Canada; ${ }^{2}$ Swale \\ Rock Marine Research, 3649 Place Road, Nanaimo, BC, V9T 1M9, Canada
}

\begin{abstract}
We compared: 1) rearing mortality, 2) size at release (mean length), 3) jack, male and female sizes, and 4) jack, female, and adult returns of coho salmon (Oncorhynchus kisutch) from three consecutive brood years reared at the Nitinat River hatchery using a conventional or a semi-natural rearing method. The semi-natural method included feeding restrictions, shading of the rearing ponds, lower rearing temperature and rearing densities, exposure to a predator and a volitional release. We found no significant effects of brood year or rearing method on rearing mortality; it was significantly lower during the marking to release phase than during the other two phases (eyed-egg to ponding, ponding to marking). Conventionally reared smolts were significantly longer. Conventionally reared males were longer. As a proportion of number of smolts released, semi-natural rearing produced $86 \%$ fewer jacks, the same proportion of females and $15 \%$ more adults. Adult production trends, described as marine survival rate (returning adults $\bullet$ smolt $^{-1}$ ) for Nitinat River Hatchery coho, and as $\ln$ recruits - female spawner ${ }^{-1}$ for a nearby wild coho population, were similar. Jacking rates were lower in Nitinat River hatchery coho than for the nearby wild coho population. We concluded that the semi-natural rearing methodology produces adult fish more efficiently than the conventional rearing method does, and at $73 \%$ of the cost.
\end{abstract}

Keywords: Hatcheries, production, salmon, semi-natural rearing, survival.

\section{INTRODUCTION}

Semi-natural rearing is a strategy used to produce salmon smolts. The original intent was to use enhanced natural rearing areas to reduce the cost of smolt production [1]. Recently, semi-natural rearing has come to mean modifying existing hatchery facilities to provide a more natural rearing setting [2]. The goal is to increase adult return by producing a smolt that resembles more closely a wild one while minimizing negative interactions between wild and hatchery fish.

Considerable effort has been expended to explore the influence of facets of semi-natural rearing (natural food [e.g. 3], cover [e.g. 4], natural substrate [e.g. 5], exercise [e.g. 6], varying rearing period length [7] and predator avoidance training [e.g. 5, 8-10]) on the post-release survival of smolts [11]; most of this research is a product of the Natural Rearing Enhancement System research programme [12-14] of the American National Marine Fisheries Service. Most investigations tested the effect of semi-natural rearing in the hatchery setting [e.g. 3]. Studies that measured post-release survival showed mixed results for freshwater [no effect: 6,8 , 15; positive effect: 5,10 ] or smolt-to-adult survival [negative effect: 16; no effect: 15, 17, 18; positive effect: 19] and on jacking rate [no effect: 17; lower for semi-naturally reared fish; 18 (based on our re-analysis of the data)].

Our study evaluated the effectiveness of a semi-natural rearing methodology for coho salmon (Oncorhynchus

*Address correspondence to this author at Swale Rock Marine Research, 3649 Place Road, Nanaimo, V9T 1M9, B. C. Canada; Tel: 250-816-6726; Email: rtanasichuk@shaw.ca kisutch) at the Canadian Department of Fisheries and Oceans' Nitinat River hatchery, located on the southwest coast of Vancouver Island. Experimental groups were incubated at lower temperatures and densities in ponds with some shade, fed less, fed a natural marine diet (euphausiids), exposed to a predator $(O$. clarkii) and released volitionally at a smaller size. We tested the null hypotheses that there was no significant effect of rearing method on: 1) rearing mortality and 2) return of jacks and adults expressed as returns per smolt.

\section{MATERIALS AND METHODOLOGY}

\section{Incubation/Rearing Conditions}

All experiments were conducted at the Canadian Department of Fisheries and Oceans' Nitinat River Hatchery which is located on the southwest coast of Vancouver Island. Progeny originated from the same egg takes in each year. Incubation conditions are listed in Table $\mathbf{1}$. They were consistent over brood years and only the incubation containers and temperatures differed between conventional and seminaturally reared fish. Otolith thermal marking [20] was used to distinguish the rearing groups. Table 2 lists early rearing (from ponding to marking) conditions and Table $\mathbf{3}$ presents information including rearing density and water flows. Late rearing (from marking to release) conditions are listed in Table 4. Conventionally reared fish were moved to early rearing conditions sooner because the eggs incubated in warmer water; consequently photoperiod and time spent under early and late rearing conditions differed between treatment groups. As shown in Tables $\mathbf{2}$ and 4, fish were fed at rates to reach a target size at release; the targets were $20 \mathrm{~g}$ 
for conventionally reared fish, which is typical, and $10 \mathrm{~g}$ for semi-naturally reared fish, which is the maximum observed size of wild smolts. Semi-naturally reared fish were held in ponds which were shaded to some extent, fed less and released volitionally at a smaller size. Semi-naturally and conventionally reared fish were exposed to river water as of October and March respectively. Semi-natural fish were presented with euphausiids as prey during the last three weeks of rearing; euphausiids were introduced in a subsurface jet of well water. Final rearing densities ranged between 2 and 3.5 times greater for conventionally reared fish and these fish were between 1.6 and 2.3 times heavier at release. Fish were released simultaneously but semi-naturally reared fish left volitionally.

Table 1. Incubation conditions for all brood years of coho reared conventionally or semi-naturally at the Nitinat River Hatchery.

\begin{tabular}{|c|c|}
\hline \multicolumn{2}{|c|}{ Smolt Type } \\
\hline Conventional & \multicolumn{1}{|c|}{ Semi-Natural } \\
\hline \hline \multicolumn{2}{|c|}{ First incubation (pre-eyed) } \\
\hline All Females screened for BKD with eggs from each female kept in separate \\
trays
\end{tabular}

\section{Fish Sampling}

Yearlings were sampled in May before release. A subsample was collected using a dipnet from the conventional or semi-natural rearing pond. Total length $(\mathrm{mm})$ and total mass (g) were measured for between 100 and 199 yearlings for each brood year $\mathrm{x}$ rearing method category.

Jacks and adults were sampled when they returned to the hatchery. Jacks were identified by length because, based on historic returns, jacks are always at least $10 \mathrm{~cm}$ shorter than mature males and there are no jills. All fish returning to the hatchery were counted and sexed, and subsamples of finclipped fish were collected for otolith analysis. Subsampling was at the rate of $20 \%$ of the daily return so that collections were distributed over the return migration. The sub-sampling strategy was to collect otoliths from 150 jacks and 250 adults. Total length $(\mathrm{mm})$ and sex were recorded for each fish in a subsample.

Table 2. Early rearing (ponding to marking) methods for all brood years of coho reared conventionally or seminaturally at the Nitinat River Hatchery. BWD body weight per day.

\begin{tabular}{|c|c|c|}
\hline \multirow{2}{*}{$\begin{array}{c}\text { Rearing } \\
\text { Condition }\end{array}$} & Conventional & Semi-Natural \\
\cline { 2 - 4 } $\begin{array}{c}\text { Container } \\
\text { type }\end{array}$ & $\begin{array}{c}6.92 \times 1.51 \times 1.22 \text { m deep out- } \\
\text { door aluminum troughs with } \\
\text { baffles }\end{array}$ & $\begin{array}{c}2.20 \times 1.90 \times 0.35 \text { m deep } \\
\text { indoor concrete raceways }\end{array}$ \\
\hline \hline Ponding & Trays carried to troughs & $\begin{array}{c}\text { Fry moved volitionally to } \\
\text { concrete raceways }\end{array}$ \\
\hline Feeding & $\begin{array}{c}\text { Fed 1.8 \% BWD to 1.5 grams } \\
\text { then reduced to } 1 \% \text { BWD to } \\
\text { slow growth }\end{array}$ & $\begin{array}{c}\text { Fed 1.8\% BWD to 0.6 gram } \\
\text { then reduced to 1\% BWD to } \\
\text { slow growth }\end{array}$ \\
\hline Marking & \multicolumn{2}{|c|}{ Fin-clipped "NUTRA"; } \\
\hline $\begin{array}{c}\text { Photo- } \\
\text { period }\end{array}$ & $\begin{array}{c}\text { Differed as a consequence of earlier metamorphosis (45 - 60 } \\
\text { days) of conventionally reared fish }\end{array}$ \\
\hline
\end{tabular}

\section{Statistical Analyses}

We tried to use analyses of variance (ANOVA) to test the significance of the effects of brood year and rearing method on rearing mortality, pre-release length, and returning length. A three-way ANOVA without replication was used to test for significant effects of brood year, rearing method and rearing phase on rearing mortality. The tests for effects on size were to be factorial analyses and include all simple and higher-order interactions when possible. Tukey's HSD test would be used to identify which least squares means differed significantly for all ANOVA's. We examined the studentized residuals and leverage coefficients to test for outliers before accepting the results of the tests. Statistically significant outliers were defined as data where the studentized residuals| were greater than 2.5 and the leverage coefficients were greater than 4 divided by the sample size [21]. Studentized residuals for the analysis of the effects of brood year, rearing method, sex and all possible interactions on adult length were not normally distributed before or after logtransforming length. We were able to test the effects of brood year and rearing method on returning female size using a two-way analysis of variance without replication. However, there was no instance when un-transformed or logtransformed male lengths, and one- or two-way analyses of variance, generated normally distributed studentized residuals. Therefore, we used the Kruskal-Wallis test, accompanied by the Steel-Dwass method for non-parametric all-pairs comparisons of maximum rank sums, to evaluate the effect of brood year on male length, and the Wilcoxon test to evaluate the effect of rearing method on length. The KruskalWallis test was also used to compare ranks of marine survival rate and $\ln$ recruits $\bullet$ female spawner ${ }^{-1}$, blocked by return year. 
Table 3. Rearing densities, water flow, rearing periods and release characteristics for all brood years of coho reared conventionally or semi-naturally at the Nitinat River Hatchery.

\begin{tabular}{|c|c|c|c|c|c|c|}
\hline \multirow{3}{*}{ Factor } & \multicolumn{6}{|c|}{ Brood Year } \\
\hline & \multicolumn{2}{|c|}{2002} & \multicolumn{2}{|c|}{2003} & \multicolumn{2}{|c|}{2004} \\
\hline & Conventional & Semi-natural & Conventional & Semi-natural & Conventional & Semi-natural \\
\hline No. fry Ponded & 249,271 & 123,734 & 175,475 & 115,090 & 112,999 & 112,339 \\
\hline Max. early rearing flows $\left(\mathrm{kg} \bullet 1^{-1} \bullet \mathrm{min}^{-1}\right)$ & 0.5 & $0.1-0.3$ & 0.5 & $0.1-0.3$ & 0.5 & $0.1-0.3$ \\
\hline Early rearing period (D/M) & $12 / 02$ to $02 / 06$ & $\begin{array}{c}08 / 04 \text { to } 11- \\
18 / 08\end{array}$ & $28 / 01$ to $02 / 05$ & $\begin{array}{c}10 / 04 \text { to } 12- \\
17 / 08\end{array}$ & $24 / 01$ to $07 / 06$ & $\begin{array}{c}30 / 03 \text { to } 27 / 06- \\
08 / 07\end{array}$ \\
\hline Max. final rearing flows $\left(\mathrm{kg} \bullet 1^{-1} \bullet \min ^{-1}\right)$ & \multicolumn{6}{|c|}{0.5} \\
\hline Max. final rearing density $\left(\mathrm{kg} \bullet \mathrm{m}^{-3}\right)$ & 7 & 2 & 12 & 6 & 12 & 6 \\
\hline Mean release mass $(\mathrm{g})$ & 21 & 9.1 & 15.4 & 9.8 & 15.1 & 7.7 \\
\hline Release dates (D/M) & $05 / 05$ & $09 / 05$ & $04 / 05$ & $04 / 05$ & $05 / 05$ & $05 / 05$ \\
\hline Release conditions & $\begin{array}{l}\text { Fish flushed } \\
\text { into a channel } \\
\text { which was } \\
\text { transitional to } \\
\text { the river }\end{array}$ & $\begin{array}{l}\text { Hatchery water } \\
\text { level reduced } \\
\text { and fish left } \\
\text { volitionally } \\
\text { over five days }\end{array}$ & $\begin{array}{l}\text { Fish flushed } \\
\text { into a channel } \\
\text { which was } \\
\text { transitional to } \\
\text { the river }\end{array}$ & $\begin{array}{l}\text { Hatchery water } \\
\text { level reduced } \\
\text { and fish left } \\
\text { volitionally } \\
\text { over five days }\end{array}$ & $\begin{array}{l}\text { Fish flushed } \\
\text { into a channel } \\
\text { which was } \\
\text { transitional to } \\
\text { the river }\end{array}$ & $\begin{array}{l}\text { Hatchery water } \\
\text { level reduced } \\
\text { and fish left } \\
\text { volitionally } \\
\text { over five days }\end{array}$ \\
\hline
\end{tabular}

Table 4. Late rearing (marking to release) methods for all brood years of coho reared conventionally or semi-naturally at the Nitinat River Hatchery.

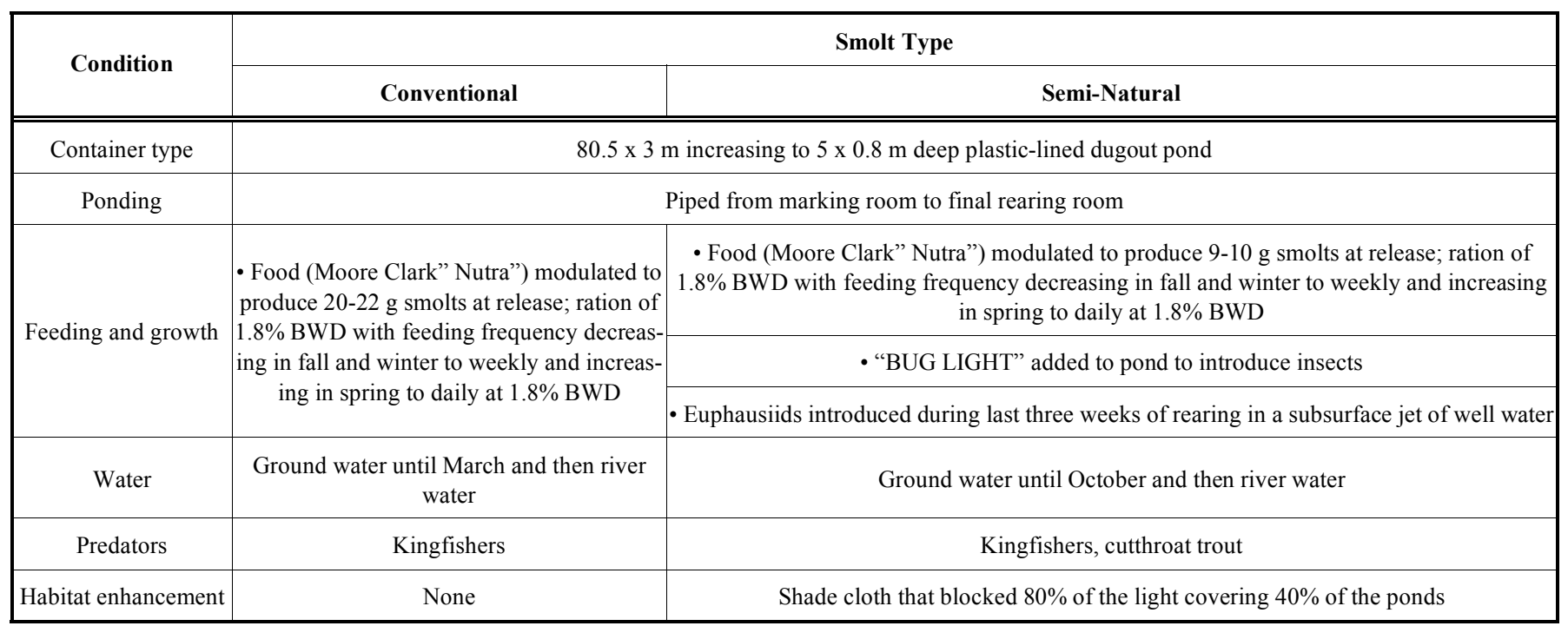

The Cochran-Mantel-Haenszel test was used to evaluate if the proportions of returning jacks, females or adults were independent of rearing method over the three brood years. Exploitation rates during the study period were estimated as 5\% (C. Lynch, DFO, Vancouver, B. C., pers. comm.) so we accepted the number of fish returning to the hatchery as total return. The statistics that we used in the analyses were number of fish returning and number of fish released.

\section{RESULTS}

\section{Rearing/Pre-Release}

We found that there was no significant effect of rearing method on incubation mortality and that conventionally reared fish were longer. Rearing mortalities by brood year, period and rearing method are presented in Table 5. Mortality did not differ significantly over brood years, or 
Table 5. Rearing mortality (proportion) of coho reared conventionally or semi-naturally at the Nitinat River Hatchery by brood year, rearing method and rearing period. EP - eyed egg to ponding, PM - ponding to marking, MR - marking to release.

\begin{tabular}{|c|c|c|c|c|c|c|}
\hline \multirow[b]{2}{*}{ Brood year } & \multicolumn{6}{|c|}{ Rearing Methodology } \\
\hline & EP & $\mathbf{P M}$ & MR & EP & $\mathbf{P M}$ & MR \\
\hline 2002 & 0.033 & 0.038 & 0.008 & 0.023 & 0.035 & 0.007 \\
\hline 2004 & 0.047 & 0.09 & 0.026 & 0.05 & 0.05 & 0.019 \\
\hline
\end{tabular}

between rearing methods, but it was significantly lower $(p=0.0056)$ during the Marking to Release rearing period. Pre-release length of conventionally reared fish (least squares mean length $=116 \mathrm{~mm})$ was significantly $(p=1.8 \mathrm{e}-$ $170)$ greater than for semi-naturally reared fish (least squares mean length $=91 \mathrm{~mm}$ ).

\section{Returns}

There was a significant effect of brood year on jack length, significant effects of brood year and rearing method on the length of males, and a significant effect of brood year on the length of returning females (Table 6). Median jack length was affected significantly $(p=7.28 \mathrm{e}-6)$ by brood year; it was lower in 2005 (least squares mean $=259 \mathrm{~mm}$ ) than in 2004 (least squares mean=286 $\mathrm{mm}$ ) and 2006 (least square mean $=288 \mathrm{~mm})$. Males were significantly $(p=9 \mathrm{e}-10)$ smaller in the 2007 return year (median length=481 $\mathrm{mm}$ ) than in 2005 (median length=530 $\mathrm{mm}$ ) and 2006 (median length $=520 \mathrm{~mm}$ ). Male coho originating from conventional rearing were significantly $(p=0.0035)$ longer (median length $=515 \mathrm{~mm}$ ) than semi-naturally reared males (median length $=494 \mathrm{~mm}$ ). There was a significant effect ( $p=9.11 \mathrm{e}-51)$ of brood year on female length; least squares mean lengths differed significantly among all return years $(560 \mathrm{~mm}$ in $2005,588 \mathrm{~mm}$ in 2006, and $513 \mathrm{~mm}$ in 2007).

Jack production was significantly lower, female production the same, and adult production significantly greater for semi-naturally reared fish (Table 7). Based on odds ratios, jack production for semi-naturally reared fish was $14 \%$ $(p=3.92 \mathrm{e}-63)$ of that for conventionally reared ones, female production was equal $(105 \%)$ and adult return was $15 \%$ greater $(p=4.30 \mathrm{e}-39)$.

Fig. (1) shows that variations in marine survival rates for the Hatchery fish, estimated as the proportion of smolts returning as adults, were comparable to changes in $\ln$ recruits $\bullet$ female spawner ${ }^{-1}$ (S. Baillie, Fisheries and Oceans Canada, Nanaimo, B. C. pers. comm.) for coho from Carnation Creek, located about $50 \mathrm{~km}$ from the Hatchery. There was no significant difference $(p=0.67)$ in rank sums of marine survival rate and $l n$ recruits per female spawner blocked by brood year.

Fig. (2) shows that jacking rate, estimated as the proportion of jacks to jack and adult return for a given brood year, were lower than those for Carnation Creek fish (S. Baillie, Fisheries and Oceans Canada, Nanaimo, B. C. pers. comm.). Semi-natural and conventional rearing produced $0.008(p=0)$ and $0.07(p=0)$ the proportion jacks that Carnation Creek wild coho did for the 2002-04 brood years.

\section{DISCUSSION}

The results of our study show that the semi-natural rearing methodology generates a significantly greater return of adult fish than conventional rearing does and we found no significant effects of rearing conditions on pre-release survival. Only one study [16] reported a negative effect of seminatural rearing on smolt-to-adult survival, and it appears that

Table 6. Median length of returning fish reared conventionally or semi-naturally at the Nitinat River Hatchery.

\begin{tabular}{|c|c|c|c|c|}
\hline \multirow{2}{*}{ Brood Year } & \multirow{2}{*}{ Source } & \multicolumn{3}{|c|}{ Median Length (mm) } \\
\cline { 3 - 5 } & & Jack & Male & 520 \\
\hline \hline 2002 & Conventional & 290 & 534 & 555 \\
\hline 2002 & Semi-natural & 285 & 530 & 562 \\
\hline 2003 & Conventional & 260 & 500 & 580 \\
\hline 2003 & Semi-natural & 240 & 487 & 521 \\
\hline 2004 & Conventional & 295 & 474 & 474 \\
\hline 2004 & Semi-natural & 286 & & 5 \\
\hline
\end{tabular}


Table 7. Number of returning conventionally or semi-naturally reared coho sampled at the Nitinat River Hatchery by brood year, maturity and sex. Number of fish is estimated as $\mathbf{n}_{\text {sampled }} \cdot \operatorname{sampling}$ rate $^{-1}$.

\begin{tabular}{|c|c|c|c|c|c|c|c|c|c|}
\hline \multirow{2}{*}{ Brood year } & \multirow{2}{*}{ Source } & \multicolumn{4}{|c|}{ n } & \multicolumn{2}{|c|}{ Sampling rate } & \multicolumn{4}{c|}{ Number of fish } \\
\cline { 3 - 9 } & & Jack & Male & Female & Jack & Adult & Jacks & Males & Females \\
\hline \hline 2002 & Conventional & 157 & 71 & 50 & 0.28 & 0.02 & 560 & 3550 & 2500 \\
\hline 2002 & Semi-natural & 7 & 43 & 26 & 0.28 & 0.02 & 25 & 2150 & 1300 \\
\hline 2003 & Conventional & 43 & 84 & 82 & 0.72 & 0.57 & 60 & 147 & 144 \\
\hline 2003 & Semi-natural & 5 & 69 & 70 & 0.72 & 0.57 & 7 & 121 \\
\hline 2004 & Conventional & 55 & 113 & 115 & 0.44 & 0.22 & 125 & 514 & 523 \\
\hline 2004 & Semi-natural & 14 & 196 & 136 & 0.44 & 0.22 & 32 & 891 & 618 \\
\hline
\end{tabular}

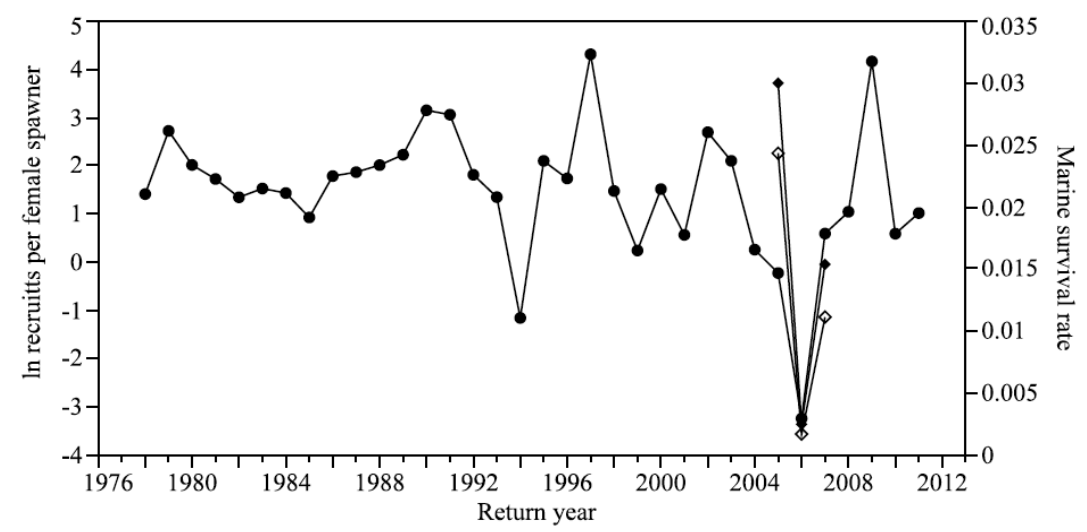

Fig (1). Comparison of marine survival rates (adult return $-\operatorname{smolt}^{-1}$ ) for Nitinat River Hatchery conventionally (open diamond) and seminaturally (filled diamond) reared coho and $\ln$ recruits per female spawner (filled circle) for Carnation Creek wild coho.

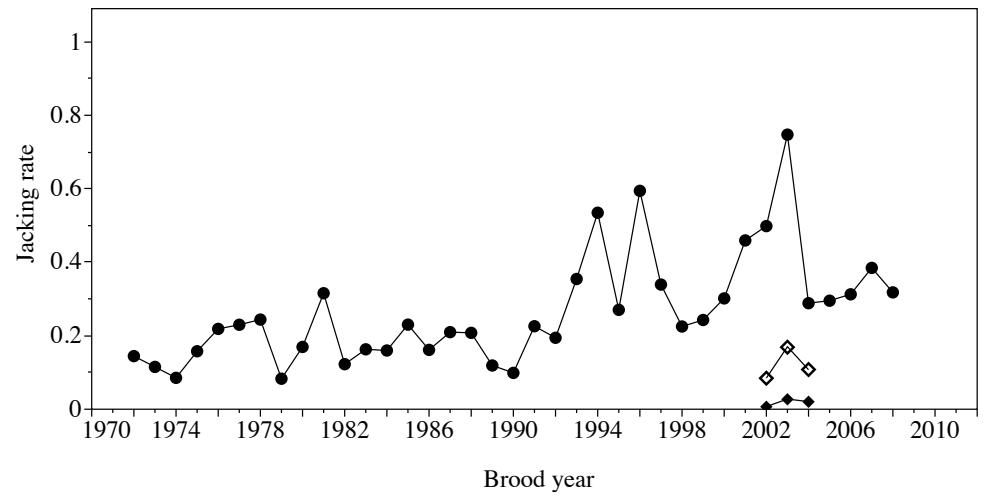

Fig (2). Time series of jacking rates for conventionally (open diamond) and semi-naturally (filled diamond) reared Nitinat River Hatchery coho and for Carnation Creek wild coho (filled circle).

semi-natural rearing provides an option to at least maintain or, in the case of this report, improve adult production, and at a lower cost. It is important to note that testing of the effectiveness of hatchery augmentation has to be comprehensive and consider marine influences as well. It is conceivable that the poor survival rate for the 2003 brood year could have been attributed to a unique aspect of the rearing methodology for those fish. However, the synchronous dramatic decline in In recruits•female spawner ${ }^{-1}$ for Carnation Creek coho suggests that the poor return was likely a consequence of a common marine effect. (R. Tanasichuk (unpubl. res.) found in an analysis that included early marine prey, competitor and predator abundances, that most of the variation (74\%) in $\ln$ recruits - female spawner ${ }^{-1}$ for Carnation Creek coho is accounted for by female parental abundance; the observation for the 2003 brood year was a significant outlier to the regression). It is also noteworthy that the variations in survival rate for the hatchery fish vary comparably with adult production for Carnation Creek coho; this suggests that Nitinat River Hatchery coho are not at a survival disadvantage.

A number of authors $[2,17,18]$ have noted that the benefits of semi-natural rearing do not offset the loss in adult yield as a consequence of lower rearing density; however, we suggest there are important positive implications of the 
semi-natural rearing method for production and enhancement hatcheries. For production hatcheries, the benefit is a reduction in the cost of producing an adult fish [see 2], and it appears that rudimentary changes to the rearing facilities could offset the loss of production resulting from lower rearing densities. We calculated that the cost of semi-natural smolt production are $73 \%$ of the cost of smolt production using conventional rearing methods (Table 8). The positive implication for enhancement strategy would be producing a smolt that would be similar phenotypically to a wild fish.

Table 8. Cost comparison (\$) for raising 100,000 fry.

\begin{tabular}{|c|c|c|}
\hline \multirow{2}{*}{ Allocated Costs } & \multicolumn{2}{|c|}{ Rearing Method } \\
\cline { 2 - 3 } & Production & Semi-Natural \\
\hline \hline \multirow{2}{*}{ Commercial Pellets } & 4256.48 & 2423.48 \\
\hline Krill & 0.00 & 500.00 \\
\hline & \multicolumn{2}{|c|}{ Water Pumping } \\
\hline Incubation & 3470.69 & 1785.89 \\
\hline River water rearing & 1275.26 & 1233.79 \\
\hline Chiller & 0.00 & 497.66 \\
\hline Shade cloth & 0.00 & 167.00 \\
\hline Sum & 9002.43 & 6607.82 \\
\hline
\end{tabular}

\section{CONCLUSIONS}

We found that semi-natural rearing strategies generate more adult production than conventional rearing at about $73 \%$ the cost. Our results emphasize the importance of considering marine effects when evaluating the efficacy of hatchery enhancement experiments. Finally, semi-natural rearing appears to have the potential to create community-based salmon enhancement opportunities as eluded to in [18].

\section{CONFLICT OF INTEREST}

The authors confirm that this article content has no conflicts of interest.

\section{ACKNOWLEDGEMENTS}

We would like to thank Cheryl Lynch and Mel Sheng for their support throughout the project and Jean Richardson for her statistical insights. We also thank the reviewers for their time and valuable comments.

\section{REFERENCES}

[1] Mundie JH, Mounce DE Application of stream ecology to raising salmon smolts in high density. Verh Intern Verein Limnol 1978; 20: 2013-8.

[2] Maynard DJ, Flagg TA, Mahnken CVW. A review of seminatural culture strategies for enhancing the postrelease survival of anadromous salmonids. Am Fish Soc Symp 1995; 15: 307-14.

[3] Maynard DJ, McDowell GC, Tezak EP, Flagg TA. Effect of diet supplemented with live food on the foraging behavior of cultured fall Chinook salmon. Prog Fish-Cult 1996; 58:187-91.
[4] Berejikian BA, Tezak EP, Flagg TA, LaRae AL, Kummerow E, Mahnken CVW. Social dominance, growth and habitat use of age-0 steelhead (Oncorhynchus mykiss) grown in enriched and conventional hatchery rearing environments. Can J Fish Aquat Sci 2000; 57: 628-36.

[5] Maynard DJ, Flagg TA, Mahnken CVW, Schroder SL. Natural rearing technologies for increasing post-release survival of hatchery-reared salmon. Bull Natl Res Inst Aquacult Suppl 1996; 2: 717.

[6] Maynard DJ, Vander Haegen GE, Colt JE, McDowell GC, Flagg TA. In: Maynard D, Riley S, Berejikian B, Flagg T, Ed. Development of a Natural Rearing System to Improve Supplemental Fish Quality. BPA Rep DOE/BP-00000548-1. 2003; 54-82.

[7] Tipping JM. Adult returns of hatchery sea-run cutthroat trout reared in a semi natural pond for different periods prior to release. $\mathrm{N} \mathrm{Am} \mathrm{J}$ Aquat 2001; 63: 131-3.

[8] Berejikian BA, Smith RJF, Tezak EP, Schroder SL, Knudsen CM. Chemical alarm signals and complex hatchery rearing habitats affect antipredatory behavior and survival of chinook salmon $(\mathrm{On}$ corhynchus tshawytscha) juveniles. Can J Fish Aquat Sci 1999; 56: 830-8.

[9] Mirza RS, Chivers DP. Predator-recognition training enhances survival of brook trout: evidence from laboratory and fieldenclosure studies. Can J Zool 2000; 78: 2198-208.

[10] Maynard DJ, LaRae AL, McDowell GC, Snell GA, Flagg TA, Mahnken CVW. Effect of predator avoidance training on the post release survival of fall Chinook salmon. In: Maynard D, Berejikian B, Flagg T, Mahnken CVW, Eds. Development of a Natural Rearing System to Improve Supplemental Fish Quality. BPA Rep DOE/BP-00004768-1. 2001; 53-9.

[11] Maynard DJ, Flagg TA, Iwamoto RN, Mahnken CVW. A review of recent studies investigating seminatural rearing strategies as a tool for increasing Pacific salmon postrelease survival. Am Fish Soc Symp 2004; 44: 573-84.

[12] Maynard D, Flagg T, Mahnken C, et al. Eds. Development of a natural rearing system to improve supplemental fish quality and finally; 1991-1995 Progress Report, Project No. 199105500. BPA Rep DOE/BP-20651-1.

[13] Maynard D, Berejikian B, Flagg T, Mahnken C, Eds. development of a natural rearing system to improve supplemental fish quality, 1996-1998 Progress Report, Project No. 199105500. BPA Rep DOE/BP-00004768-1.

[14] Maynard D, Riley S, Berejikian B, Flagg T, Ed. Development of a natural rearing system to improve supplemental fish quality, Project No. 1991-05500. BPA Rep DOE/BP-00000 548-1.

[15] Fast DE, Neeley D, Lind DT, et al. Survival comparison of spring Chinook salmon reared in a production hatchery under optimal conventional and seminatural conditions. Trans Am Fish Soc 2008; 137: $1507-18$.

[16] Kostow K. Differences in juvenile phenotypes and survival between hatchery stocks and a natural population provide evidence for modified selection due to captive breeding. Can J Fish Aquat Sci 2004; 61: 577-89.

[17] Fuss H, Byrne J. Differences in survival and physiology between coho salmon reared in seminatural and conventional ponds. $\mathrm{N} \mathrm{Am} \mathrm{J}$ Aquacult 2002; 64: 267-77.

[18] Mundie JH, Mounce DE, Simpson KS. Semi-natural rearing of coho salmon, Oncorhynchus kisutch (Walbaum), smolts, with an assessment of survival to the catch and escapement. Aquat Fish Manage 1990; 21: 327-45.

[19] Tipping JM. Return rates of hatchery-produced sea-run cutthroat trout reared in a pond versus a standard or baffled raceway. Prog Fish-Cult 1998; 60: 109-13.

[20] Volk EC, Schroder SL, Grimm JJ. Otolith thermal marking. Fish Res 1999; 43: 205-19.

[21] Sokal RR, Rohlf FJ. Biometry: The principles and practice of statistics in biological research. New York: W. H. Freeman and Co. 1995.

This is an open access article licensed under the terms of the Creative Commons Attribution Non-Commercial License (http://creativecommons.org/licenses/by-nc/3.0/) which permits unrestricted, non-commercial use, distribution and reproduction in any medium, provided the work is properly cited. 